\title{
ReSearch Article \\ Correlation and path-coefficient analysis in Ramnad Mundu chilli (Capsicum annuum L.) for yield and quality traits
}

\author{
J. Phani Kumar, P. Paramaguru, T. Arumugam, N. Manikanda Boopathi and K. Venkatesan
}

\begin{abstract}
SUMMARY
The present investigation was conducted to find the correlation and path-coefficient analysis for yield and yield contributing characters in Ramnad Mundu chilli (Capsicum annuum L.) during Kharif 2018-19. The experiment was conducted on Forty-seven Mundu chilli genotypes for 15 characters, which was laid out in Randomized Complete Block Design with two replications. From correlation study dry fruit yield per plant showed highly positive correlation with number of fruits per plant $(0.971 \mathrm{G}, 0.894 \mathrm{P})$, ripened fruit yield per plant $(0.991 \mathrm{G}, 0.949 \mathrm{P})$, number of seeds per fruits $(0.383$ G, $0.32 \mathrm{P}), 1000$ seed weight $(0.369 \mathrm{G}, 0.332 \mathrm{P})$, capsaicin $\%(0.302 \mathrm{G}, 0.256 \mathrm{P})$ and number of primary branches per plant $(0.267 \mathrm{G}, 0.251 \mathrm{P})$ at both genotypic and phenotypic level. Path-coefficient analysis of different characters contributing towards the highest positive direct effect via number of fruits per plant (0.973), ripened fruit yield per plant (0.991), no. of seeds per fruit (0.383), 1000 seed weight $(0.364)$, capsaicin \% (0.302) and number of primary branches per plant $(0.267)$. Hence, direct selection based on these characters would be effective in crop improvement through plant breeding in Mundu chilli.
\end{abstract}

Key Words : Ramnad mundu chilli, Anthracnose, Colletotrichum species, Correlation, Path co-efficient analysis

How to cite this article : Kumar, J. Phani, Paramaguru, P., Arumugam, T., Boopathi, N. Manikanda and Venkatesan, K. (2021). Correlation and path-coefficient analysis in Ramnad Mundu chilli (Capsicum annuum L.) for yield and quality traits. Internat. J. Plant Sci., 16 (1): 1-6, DOI: 10.15740/HAS/IJPS/16.1/1-6, Copyright@ 2021: Hind Agri-Horticultural Society.

\section{MEMBERS OF THE RESEARCH FORUM}

Author to be contacted :

J. Phani Kumar, Horticultural College and Research Institute

(T.N.A.U.), Periyakulam (T.N.) India

Email : phani515202@gmail.com

Address of the Co-authors:

P. Paramaguru, Horticultural College and Research Institute (Women) (T.N.A.U.), Tiruchirappalli (T.N.) India

$-\bar{T}$. Arumugam and K. Venkatesan, Horticultural College and Research Institute (T.N.A.U.), Periyakulam (T.N.) India

N. Manikanda Boopathi, Department of Plant Biotechnology, Centre for Plant Molecular Biology and Biotechnology, Tamil Nadu Agricultural University, Coimbatore (T.N.) India
Article chronicle : Received : 22.10.2020; Revised : 02.11.2020; Accepted : 01.12.2020 